\title{
Stabilization of DNA Loop Structures by Large Cations
}

Shu-ichi Nakano, ${ }^{*}, \dagger$ Toshiya Ayusawa, ${ }^{\dagger}$ Yuichi Tanino, ${ }^{\dagger}$ and Naoki Sugimoto ${ }^{\dagger, \dagger}$

'Department of Nanobiochemistry, Faculty of Frontiers of Innovative Research in Science and

Technology (FIRST), Konan University, 7-1-20, Minatojima-minamimachi, Chuo-ku, Kobe, 6500047, Japan

†Fontier Institute for Biomolecular Engineering Research (FIBER), Konan University, 7-1-20, Minatojima-minamimachi, Chuo-ku, Kobe, 650-0047, Japan

\section{Supporting Information}

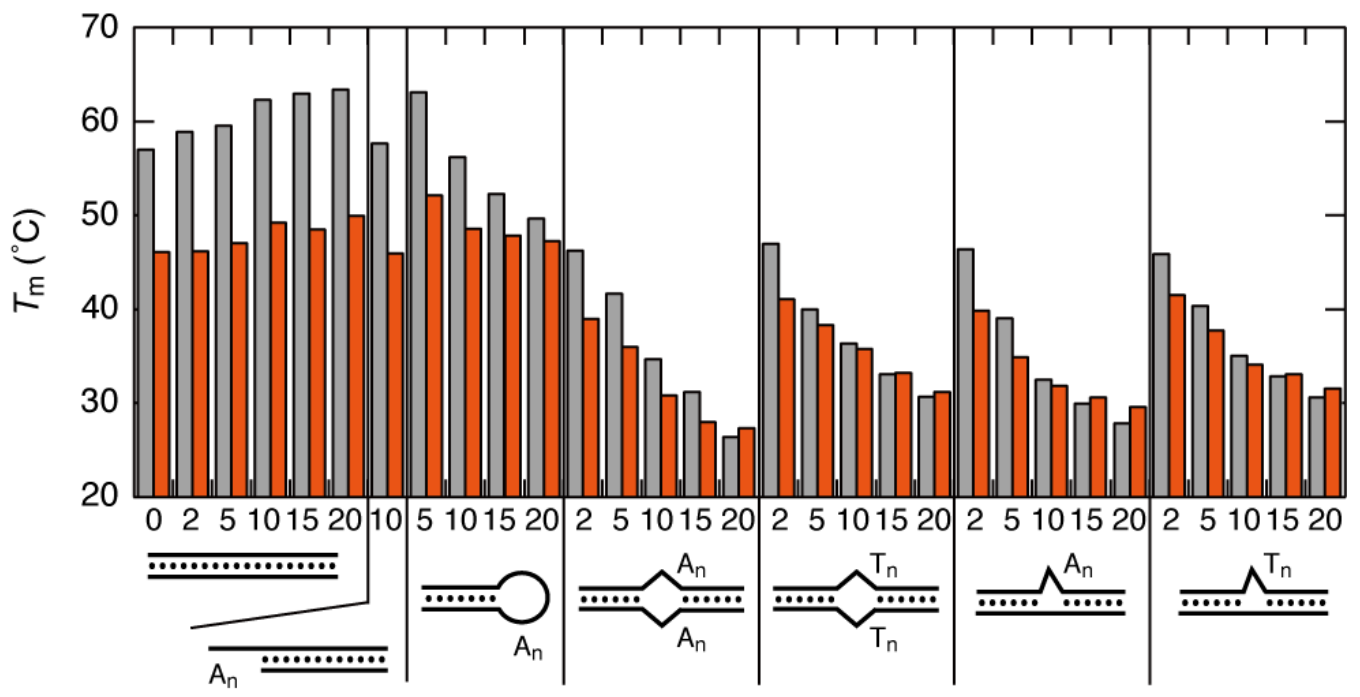

Figure S1. $T_{\mathrm{m}}$ values of DNA structures with different base-pair lengths and loop lengths in the absence (gray) and presence (red) of $100 \mathrm{mM}$ TPeACl in PBS solution. 
A

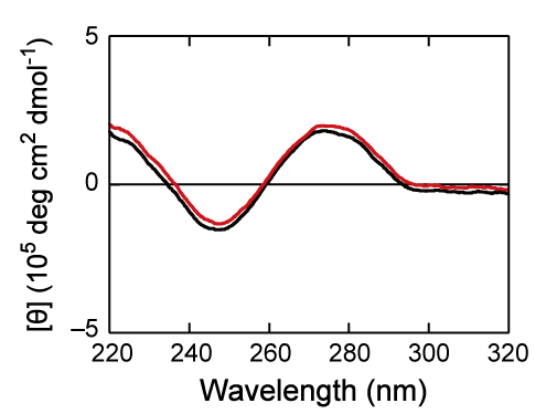

C

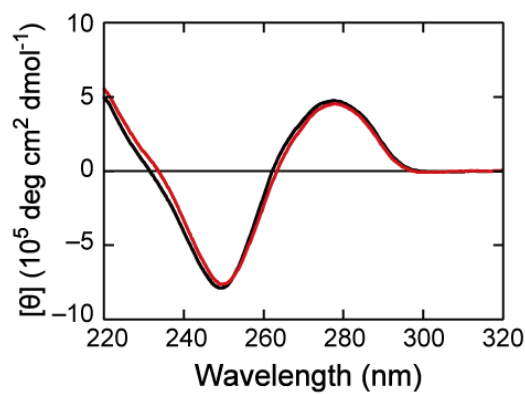

$\mathrm{B}$

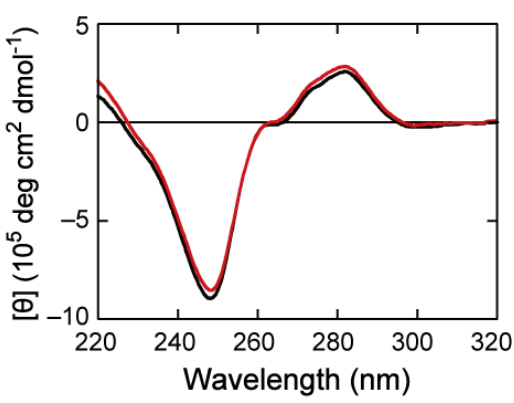

D

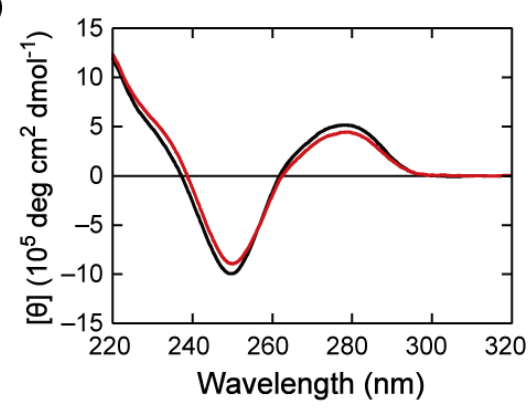

Figure S2. CD spectra of the DNA duplexes of $A_{0} / A_{0}(A), A_{10} / T_{10}(B), A_{5} / A_{5}(C)$, and $A_{10} / A_{10}(D)$ in the absence (black) and presence (red) of $100 \mathrm{mM} \mathrm{TPeACl}$ in the phosphate buffer containing a limited amount of metal ions. 


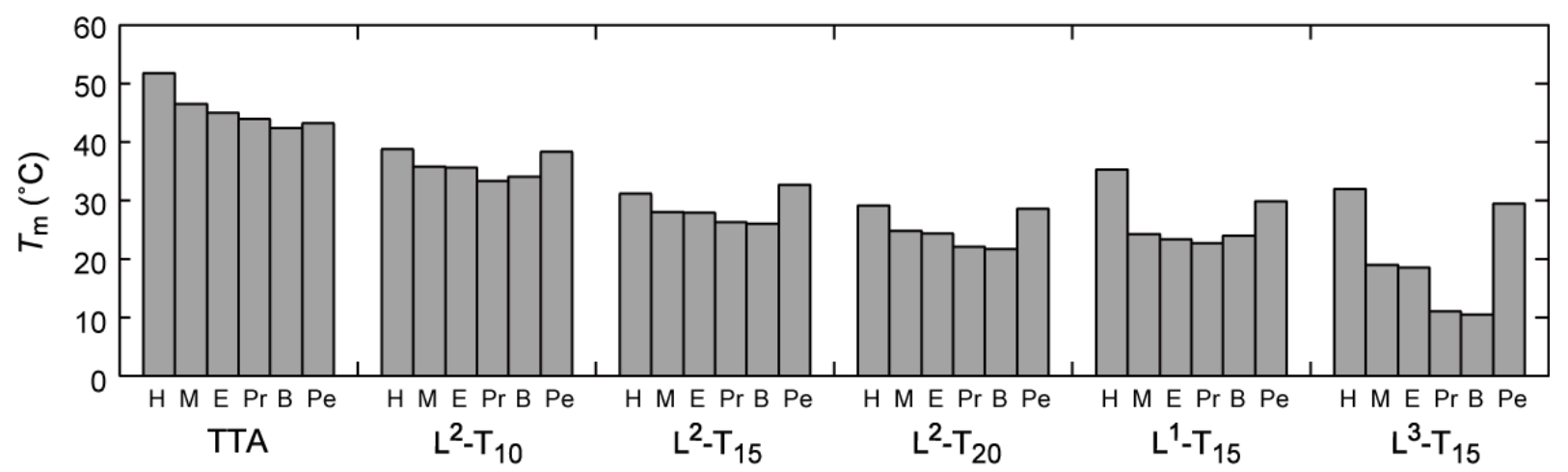

Figure S3. $T_{\mathrm{m}}$ values of the G-quadruplexes in the phosphate buffer containing $50 \mathrm{mM} \mathrm{NH}{ }_{4} \mathrm{Cl}$, TMACl, TEACl, TPrACl, TBACl, and TPeACl, indicated by H, M, E, Pr, B, and Pe, respectively. 
A

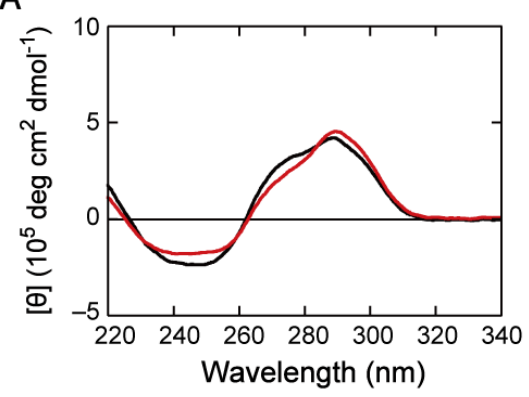

B

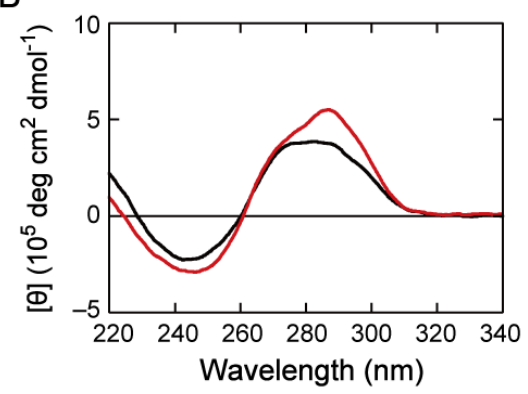

C

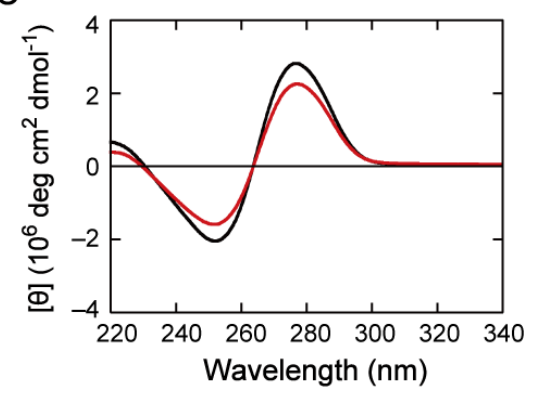

Figure S4. CD spectra of the G-quadruplexes of $\mathrm{L}^{1}-\mathrm{T}_{15}(\mathrm{~A}), \mathrm{L}^{3}-\mathrm{T}_{15}(\mathrm{~B})$, and a single-stranded $\mathrm{T}_{15}(\mathrm{C})$ in the absence (black) and presence (red) of $100 \mathrm{mM} \mathrm{TPeACl}$ in the phosphate buffer. 
Table S1. Thermodynamic Parameters for the Formation of Fully Matched Duplex and A-Loop Structures in the Absence and Presence of $100 \mathrm{mM}$ TPeACl in PBS Solution, Determined from the Plot of $T_{\mathrm{m}}^{-1}$ versus $\log \left(C_{\mathrm{t}} / 4\right)^{a}$

\begin{tabular}{llccc}
\hline sequence & buffer & $-\Delta H^{\circ}\left(\mathrm{kcal} \mathrm{mol}^{-1}\right)$ & $-\Delta S^{\circ}\left(\mathrm{cal} \mathrm{mol}^{-1} \mathrm{~K}^{-1}\right)$ & $-\Delta G^{\circ}\left(\mathrm{kcal} \mathrm{mol}^{-1}\right)$ \\
\hline $\mathrm{A}_{0} / \mathrm{A}_{0}$ & PBS & $139 \pm 9$ & $394 \pm 27$ & $17.0 \pm 1.9$ \\
& TPeACl-PBS & $147 \pm 5$ & $433 \pm 14$ & $12.5 \pm 0.5$ \\
$\mathrm{~A}_{10} / \mathrm{A}_{10}$ & PBS & $119 \pm 5$ & $356 \pm 15$ & $8.49 \pm 0.70$ \\
& TPeACl-PBS & $136 \pm 8$ & $417 \pm 26$ & $6.51 \pm 1.61$ \\
& PBS & $114 \pm 6$ & $352 \pm 19$ & $4.73 \pm 0.88$ \\
$\mathrm{~A}_{20} / \mathrm{A}_{20}$ & TPeACl-PBS & $127 \pm 6$ & $395 \pm 18$ & $4.81 \pm 0.71$ \\
\hline
\end{tabular}

${ }^{a}$ Errors were calculated based on the linearity of the plot of $T_{\mathrm{m}}{ }^{-1}$ versus $\log \left(C_{\mathrm{t}} / 4\right)$. 
Table S2. Thermodynamic Parameters for the Formation of Fully Matched Duplex and A-Loop Structures in the Absence and Presence of $100 \mathrm{mM}$ TPeACl in PBS Solution, Determined from Nonlinear Fitting of Melting Curves to a Theoretical Equation ${ }^{a}$

\begin{tabular}{llccc}
\hline sequence & buffer & $-\Delta H^{\circ}\left(\mathrm{kcal} \mathrm{mol}^{-1}\right)$ & $-\Delta S^{\circ}\left(\mathrm{cal} \mathrm{mol}^{-1} \mathrm{~K}^{-1}\right)$ & $-\Delta G^{\circ}\left(\mathrm{kcal} \mathrm{mol}^{-1}\right)$ \\
\hline $\mathrm{A}_{0} / \mathrm{A}_{0}$ & PBS & $131 \pm 6$ & $371 \pm 17$ & $16.7 \pm 0.5$ \\
& TPeACl-PBS & $144 \pm 10$ & $425 \pm 31$ & $12.5 \pm 0.3$ \\
$\mathrm{~A}_{10} / \mathrm{A}_{10}$ & PBS & $121 \pm 6$ & $364 \pm 19$ & $8.53 \pm 0.23$ \\
& TPeACl-PBS & $147 \pm 8$ & $452 \pm 27$ & $6.72 \pm 0.22$ \\
& PBS & $124 \pm 12$ & $383 \pm 40$ & $5.28 \pm 0.30$ \\
$\mathrm{~A}_{20} / \mathrm{A}_{20}$ & TPeACl-PBS & $139 \pm 7$ & $431 \pm 22$ & $5.39 \pm 0.26$ \\
\hline
\end{tabular}

${ }^{a}$ Errors were given as standard deviations of parameters determined from independently obtained melting curves. 